\title{
Teachers' Techniques in Improving Students Pronouncing Words Loudly at the First Year of MAN Batam
}

Taqiyuddin ${ }^{l}$

${ }^{1}$ Corresponding author, English Education Department, STAIN Sultan Abdurrahman, Bintan, Indonesia; taqiyuddin@stainkepri.ac.id

Received: December 31, 2020 $\quad$ Accepted: January 20, $2021 \quad$ Published: January 20, 2021

\begin{abstract}
This study aims at figuring out teaching techniques commonly and effectively used by MAN teachers to improve students' pronunciation. Moreover, the subjects are two English teachers. Meanwhile, the object of the study is the teachers' techniques in improving students pronouncing words loudly at the first year of MAN Batam. In this research, the researcher took two teachers as a respondent. The techniques of collecting data are observation and interview. Observation is used to know the teacher technique in teaching pronunciation. And interview is used to know the effectiveness of technique in teaching pronunciation. The researcher uses observations as main data collection and the interview is as to support the data needed. In addition to the data analysis, the researcher uses descriptive quantitative which applies statistical data. As for the result of this research, the researcher takes some conclusions. They are: English teacher uses drilling technique how to pronounce the word, English teacher uses repetition technique to practice and improve students pronouncing, English teacher uses backward building up technique to improve students pronouncing, and the repetition technique is the most frequently used by the teacher. Based on the analysis of data, the researcher concludes that The Teachers' Techniques in Improving Students Pronouncing Words Loudly at the first year of MAN Batam is categorized into "less".
\end{abstract}

Keywords: English Teacher; Pronunciation; Teaching technique

To cite this article: Taqiyuddin (2021). The teachers' techniques in improving students' pronunciation at the first year of MAN Batam. SALEE: Study of Applied Linguistics and English Education, 2(01). https://doi.org/10.35961/salee.v2i01.216

DOI: $10.35961 /$ salee.v2i01.216 


\section{Introduction}

Teacher is one of the important components in teaching and learning process. All of activities in the classroom are dominantly by teachers. In teaching pronunciation, the teacher should be able to make students become active in the classroom. So, the teacher needs techniques to teaching pronunciation. One of the techniques to make students active in pronouncing words loudly is by using drilling technique.

In Indonesia, English subject is learnt and taught to Junior High School, Senior High School, and even at University. KTSP has been implemented in this School. English KTSP (Education Unit Level Curriculum) in which school or an institution has authority to implement system of learning and teaching activity for particular lessons or subjects based on the curriculum applied.

KTSP has been applied since 2007 until now. English subject is taught twice a week with allocated-time of 2 meetings times 45 minutes. English teacher uses KTSP, because KTSP describes about integrated all of the languages skills; writing, speaking, reading and listening. It is clearly stated that one of the objectives of the English subject in Senior High School is developing the ability to communicate in English, either in written or oral form which covers listening, speaking, reading and writing.

In teaching and learning process, teacher is one of the human components who takes a part in the effort of forming of potential human resource. Kunandar (2007:113) says that in KTSP, teacher has been functioned as the facilitator and the mediator to help the students in learning process. They are as follows (1) providing learning experience which is conducive to the students and responsible in making process and design; (2) providing or giving the activities which is stimulating the knowledge of students and help them to express their ideas, providing the facilities which is stimulating students' thinking productively, providing the opportunity and experience; and (3) monitoring, evaluating, and showing what students' ideas.

Reading is one of the skills that must be mastered by students, especially in grasping information presented in the books, newspaper, magazine, encyclopedia, etc. When student reads book they should know how to read well and should be trained in using appropiate guessing strategies when encountering difficult words. According to Birch (2002:41) states that; there are three other possibilities for reading and each possibility involves slightly more processing work. The first type of reading, readers proceed to summon up a memory of the physical sounds in the word they are reading. The second type of reading, readers proceed even further to activate the motor commands to the mouth that are associated with the sound, so that the reader has the sensation of saying the words, but nothing is audible. The third alternative way of reading is oral reading, in which the motor commands to the mouth are actually realized and the read words are pronounced audibly.

In reading text, there are some words that student do not know how to say the words. So in this case, a teacher has play an important role to develop students' pronunciation in saying the word, Acording to Brown, (1994:160) there are some roles of teacher in teaching english, they are:

1. The teacher as a controller

The teacher is demanded to be able to control what the students do, when they should speak and what language forms they should use. 
2. The teacher as a director

In the classroom interactive, the teacher is like a conductor of an orchestra or a director of drama. It means that, the teacher keeps the learning process running smoothly and efficiently.

3. The teacher as a manager

The teacher plans lessons and modules and course so that the objectives of teaching and learning can be achieved.

4. The teacher as a facilitator

The teacher facilitates the process of learning, making learning easier for students, helping them to clear away roadblock, finding shortcuts and negotiating rough terrain.

5. The teacher as a resource

The teacher advices and council the students, when they have something to ask.

One of the elements of speaking is pronunciation. In teaching pronunciation, there are some techniques that teacher should apply in it. According to Hewings (1993:20-21) states that developing general techniques for modelling and correcting pronunciation is the basic cycle for presenting pronunciation used in many activities, they are model (say or play the recording), choral repetition, and individual repetition.

Maser (1991) in Roziana and Winda fitriyani (2002:7), pronunciation is an important aspect in speaking. Correct pronunciation can help us to understand more in communication. On the other hand, incorrect pronunciation can make misunderstanding between speaker and audience. Concerning with the important of pronunciation, there are three basic reasons to practice and develop a good English pronunciation. They are as follows:

1. It will understand us more easily when we speak to other people.

2. It will help us to hear English sounds better.

3. It is able to say a word with its correct pronunciation makes it easier to learn the words and its meaning.

Furthermore, Hewings (1993:19-20) states that there are three main ways in teaching pronunciation, namely:

1. Be aware of the likely pronunciation difficulties of students with particular firstlanguage groups and prepare activities that will focus on these problems.

2. If possible, diagnose your students' pronunciation weaknesses and plan activities that focus on these.

3. Look at the syllabus in the course book you are using and identify which parts lend themselves to work on particular areas of pronunciation.

Based on the explanation above the teacher should know student's weakness dealing with their pronunciation and look at the syllabus in the course book. So, the process of teaching run well and student understand to practice their pronunciation well.

MAN Batam is one of the Senior High Schools located in Batam, there are many students who are studying in this school. In this school, English is a compulsory subject that must be taught to the students. They have been taught by professional teachers in various disciplines, especially for teaching English, there are three English teachers in this school.

English teacher should be able to use various techniques to make the students pronouncing the words correctly. But besed on preliminary research, there are many problems found they can be seen from the phenomena, as follows:

1. English teachers do not use several techniques to explain pronunciation clearly 
2. English teachers seldom use model of instruction in teaching pronunciation in reading text.

3. English teachers do not correct student's pronunciation.

4. English teachers seldom use technique in improving students' pronunciation

In short, the researcher is interested in conducting the as well as investigating this problem and wants to know the teachers' techniques in teaching pronunciation at MAN Batam.

\section{Method}

This research is descriptive quantitative. This research describes the teachers' techniques in improving students pronouncing words loudly at the first year of MAN Batam. it was conducted at MAN Batam. The school is located in Sagulung Sub-District of Batam city J1. Brigjen Katamso No. 10.

\subsection{Respondents}

This research used descriptive quantitative, the subject of this research is all English teachers at MAN Batam and the object of this research is the teachers' techniques in improving students pronuncing words loudly. A total number of respondents was 3 teachers

\subsection{Instruments}

The test is intended to find out the teachers' techniques in improving students pronouncing words loudly. To collect the data involved to this study, the researcher applies techniques as follow:

\section{a) Observation}

According to Arikunto (2006:156), observation is an activity which is concerned toward some objects by using eyes and can be called direct observation. This method is carried out to observe the teachers' techniques in improving students pronouncing words loudly. In this technique, the researcher observes directly about activities teachers do in teaching and write some notes. The researcher needs four times to observe the teachers' techniques in improving students pronouncing words loudly.

In this observation, there are several steps which are done by the researcher. Firstly the researcher saw how did the teacher explain the material and how did the teacher use the technique. Secondly, the researcher wrote some notes about the activity of teacher in teaching. Thirdly, besides the researcher wrote some notes, the researcher used checklist form to complete the information.

b) Interview

This technique was used to obtain some data by asking some questions directly to the teacher. This is used to identify the technique that applied by the teacher. Rea and Parker (1992) in Nana Syaodih (2006:84), states several advantages from direct interview. They are:

1. Flexibility; the questions can be asked verbally or written and answered forthwith and some questions which are not clear or doubt can be clarified directly.

2. Greater complexity; the researcher can be asked the complex questions. 
3. Ability to contact hard - to - reach populations; enabling to collect the data form the sample which are difficulties to be contacted by telephone or letter.

4. High responses; possibility to give bigger answer than equate through post.

5. Assurance that instructions are followed; possibility the responder gives the answer which is expected by the researcher.

In this interview, the researcher uses semi structured. In this case, firstly interviewer asks some questions which are structured. Then, one by one the interviewer asks to more information completely. So, the answers can cover all variables with complete information. Then, the researcher wrote the result from the interview.

\subsection{Procedures}

According to Hornby (1989:240) concepts is idea underlying something general notion. In this research plan, the researcher interprets the concept into particular words in order to be operated and measured easily and clearly.

There are some teachniques to measure the teacher ways in improving student's pronuncing words loudly:

1. English teacher uses Drill technique to improve students pronouncing words loudly at the first year of MAN Batam.

2. English teacher uses same different exercise to asertain wheather or not the students can hear the phonemic contrasts.

3. English teacher uses sustituition drill technique to help the students when they have difficulties in pronouncing the word.

4. English teacher uses repetiton drill technique to pronounce the word.

5. English teacher uses transformation drill technique.

6. English teacher uses backward building up technique.

7. English teacher uses bingo technique.

8. English teacher uses brainstorming technique.

9. English teacher uses categorizing technique.

10. English teacher uses chain stories technique.

11. English teacher uses dialoques technique.

12. English teacher uses exaggeration technique.

\subsection{Data Analysis}

In this research, the data analyzed by qualitative analized. Qualitative research collects data through observation, and then, comes up with theories account for data. The theories can explain the data collected or facts which are observed. The data analysis technique used the formula as follow:

$\mathrm{P}=\frac{F}{N} x 100 \%$

Where:

$\mathrm{P}=$ Percentage

$\mathrm{F}=$ Number of Frequency

$\mathrm{N}=$ Total of score

This technique is called descriptive technique with percentage. Suharsimi (2002:213) 
After that the percentage is interrupted into qualitative words, the researcher finds out the category of the teachers' techniques in improving students pronouncing words loudly at the first year of Man Batam can be seen as follows:

Table 1. The category of teachers' techniques in improving students pronouncing words loudly

\begin{tabular}{cc}
\hline Category & Range \\
\hline Very good & $80 \%-100 \%$ \\
\hline Good & $70 \%-79 \%$ \\
\hline Enough & $60 \%-69 \%$ \\
\hline Less & $50 \%-59 \%$ \\
\hline Bad & $0 \%-49 \%$
\end{tabular}

Suharsimi (2002:213)

\section{Finding and Discussion}

3.1. The observation Result of English Teacher "A" dealing with the techniques In improving students pronouncing words loudly.

The data presented in this study become the result of observation toward the teachers' techniques in improving students pronouncing words loudly. This observation is held in eight meetings. The result of observation can be seen in the following explanation:

Tabel 2: The observation Result of English Teacher "A" dealing with the techniques in improving students pronouncing words loudly.

\begin{tabular}{|c|c|c|c|c|c|c|c|c|c|c|c|}
\hline \multirow{2}{*}{ No } & \multirow{2}{*}{$\begin{array}{l}\text { Number of } \\
\text { Items }\end{array}$} & \multicolumn{8}{|c|}{ Observation time } & \multirow{2}{*}{$\begin{array}{c}\text { Total } \\
\text { (F) }\end{array}$} & \multirow{2}{*}{$\begin{array}{c}\text { Persentage } \\
(\%)\end{array}$} \\
\hline & & 1 & 2 & 3 & 4 & 5 & 6 & 7 & 8 & & \\
\hline 1 & $\begin{array}{l}\text { English teacher } \\
\text { uses Drill } \\
\text { technique to } \\
\text { improve students } \\
\text { pronouncing } \\
\text { words loudly. }\end{array}$ & $\sqrt{ }$ & $\sqrt{ }$ & - & $\sqrt{ }$ & $\sqrt{ }$ & - & $\sqrt{ }$ & $\sqrt{ }$ & 6 & $75 \%$ \\
\hline 2 & $\begin{array}{l}\text { English teacher } \\
\text { uses same } \\
\text { different exercise } \\
\text { to asertain } \\
\text { wheather or not } \\
\text { the students can } \\
\text { hear the } \\
\text { phonemic } \\
\text { contrasts. }\end{array}$ & - & $\sqrt{ }$ & - & - & $\sqrt{ }$ & - & - & $\sqrt{ }$ & 3 & $37.5 \%$ \\
\hline 3 & $\begin{array}{l}\text { English teacher } \\
\text { uses sustituition } \\
\text { drill technique to } \\
\text { help the students } \\
\text { when they have } \\
\text { difficulties in }\end{array}$ & $\sqrt{ }$ & - & - & $\sqrt{ }$ & $\sqrt{ }$ & $\sqrt{ }$ & - & - & 4 & $50 \%$ \\
\hline
\end{tabular}




\begin{tabular}{|c|c|c|c|c|c|c|c|c|c|c|c|}
\hline & $\begin{array}{l}\text { pronouncing the } \\
\text { word. }\end{array}$ & & & & & & & & & & \\
\hline 4 & $\begin{array}{l}\text { English teacher } \\
\text { uses repetiton } \\
\text { drill technique to } \\
\text { pronounce the } \\
\text { word. }\end{array}$ & $\sqrt{ }$ & $\sqrt{ }$ & $\sqrt{ }$ & - & $\sqrt{ }$ & $\sqrt{ }$ & $\sqrt{ }$ & $\sqrt{ }$ & 7 & $87.5 \%$ \\
\hline 5 & $\begin{array}{l}\text { English teacher } \\
\text { uses } \\
\text { transformation } \\
\text { drill technique. }\end{array}$ & $\sqrt{ }$ & - & $\sqrt{ }$ & $\sqrt{ }$ & - & $\sqrt{ }$ & - & - & 4 & $50 \%$ \\
\hline 6 & $\begin{array}{l}\text { English teacher } \\
\text { uses backward } \\
\text { building up } \\
\text { technique. }\end{array}$ & $\sqrt{ }$ & $\sqrt{ }$ & - & $\sqrt{ }$ & $\sqrt{ }$ & $\sqrt{ }$ & $\sqrt{ }$ & - & 6 & $75 \%$ \\
\hline 7 & $\begin{array}{c}\text { English teacher } \\
\text { uses bingo } \\
\text { technique }\end{array}$ & - & $\sqrt{ }$ & - & $\sqrt{ }$ & - & - & $\sqrt{ }$ & - & 3 & $37.5 \%$ \\
\hline 8 & $\begin{array}{c}\text { English teacher } \\
\text { uses } \\
\text { brainstorming } \\
\text { technique. }\end{array}$ & - & $\sqrt{ }$ & $\sqrt{ }$ & - & $\sqrt{ }$ & $\sqrt{ }$ & - & - & 4 & $50 \%$ \\
\hline 9 & $\begin{array}{l}\text { English teacher } \\
\text { uses categorizing } \\
\text { technique }\end{array}$ & $\sqrt{ }$ & - & - & $\sqrt{ }$ & - & - & $\sqrt{ }$ & - & 3 & $37.5 \%$ \\
\hline 10 & $\begin{array}{l}\text { English teacher } \\
\text { uses chain stories } \\
\text { technique. }\end{array}$ & - & $\sqrt{ }$ & - & - & $\sqrt{ }$ & - & $\sqrt{ }$ & - & 3 & $37.5 \%$ \\
\hline 11 & $\begin{array}{l}\text { English teacher } \\
\text { uses dialoques } \\
\text { technique }\end{array}$ & - & $\sqrt{ }$ & $\sqrt{ }$ & - & $\sqrt{ }$ & - & - & $\sqrt{ }$ & 4 & $50 \%$ \\
\hline 12 & $\begin{array}{c}\text { English teacher } \\
\text { uses exaggeration } \\
\text { technique }\end{array}$ & - & - & $\sqrt{ }$ & - & - & $\sqrt{ }$ & - & - & 2 & $25 \%$ \\
\hline & TOTAL & 6 & 8 & 5 & 6 & 8 & 6 & 6 & 4 & & \\
\hline \multicolumn{2}{|r|}{ Percentage $(\%)$} & $50 \%$ & $66.6 \%$ & $41.6 \%$ & $50 \%$ & $66.6 \%$ & $50 \%$ & $50 \%$ & $33.3 \%$ & & $51.0 \%$ \\
\hline
\end{tabular}

From the table above, it can be analyzed that almost normal eventhough there are there techniques done well by the teacher, namely : driling technique 75\%, Repetiton drill technique $87.5 \%$, and Backward building up technique $75 \%$.

\subsection{The Observation Result of English Teacher " $B$ " dealing with the techniques in} improving students pronouncing word loudly.

From the table 2 below, it can be analyzed that almost normal eventhough there are there techniques done well by the teacher, namely : driling technique $62.5 \%$, Repetiton drill technique $87.5 \%$, and Backward building up technique $75 \%$. 
Tabel 2: The observation Result of English Teacher "B" dealing with the techniques In improving students pronouncing words loudly.

\begin{tabular}{|c|c|c|c|c|c|c|c|c|c|c|c|}
\hline \multirow{2}{*}{ No } & \multirow{2}{*}{$\begin{array}{l}\text { Number of } \\
\text { Items }\end{array}$} & \multicolumn{8}{|c|}{ Observation time } & \multirow{2}{*}{$\begin{array}{c}\text { Total } \\
\text { (F) }\end{array}$} & \multirow{2}{*}{$\begin{array}{c}\text { Persentage } \\
(\%)\end{array}$} \\
\hline & & 1 & 2 & 3 & 4 & 5 & 6 & 7 & 8 & & \\
\hline 1 & $\begin{array}{l}\text { English teacher } \\
\text { uses Drill } \\
\text { technique to } \\
\text { improve } \\
\text { students } \\
\text { pronouncing } \\
\text { words loudly. }\end{array}$ & $\sqrt{ }$ & $\sqrt{ }$ & - & $\sqrt{ }$ & $\sqrt{ }$ & - & - & $\sqrt{ }$ & 5 & $62.5 \%$ \\
\hline 2 & $\begin{array}{l}\text { English teacher } \\
\text { uses same } \\
\text { different } \\
\text { exercise to } \\
\text { asertain } \\
\text { wheather or not } \\
\text { the students can } \\
\text { hear the } \\
\text { phonemic } \\
\text { contrasts. }\end{array}$ & - & $\sqrt{ }$ & - & - & $\sqrt{ }$ & $\sqrt{ }$ & - & $\sqrt{ }$ & 4 & $50 \%$ \\
\hline 3 & $\begin{array}{c}\text { English teacher } \\
\text { uses sustituition } \\
\text { drill technique } \\
\text { to help the } \\
\text { students when } \\
\text { they have } \\
\text { difficulties in } \\
\text { pronouncing the } \\
\text { word. }\end{array}$ & $\sqrt{ }$ & - & - & $\sqrt{ }$ & $\sqrt{ }$ & - & - & - & 3 & $37.5 \%$ \\
\hline 4 & $\begin{array}{l}\text { English teacher } \\
\text { uses repetiton } \\
\text { drill technique } \\
\text { to pronounce } \\
\text { the word. }\end{array}$ & $\sqrt{ }$ & $\sqrt{ }$ & - & $\sqrt{ }$ & $\sqrt{ }$ & $\sqrt{ }$ & $\sqrt{ }$ & $\sqrt{ }$ & 7 & $87.5 \%$ \\
\hline 5 & $\begin{array}{l}\text { English teacher } \\
\text { uses } \\
\text { transformation } \\
\text { drill technique. }\end{array}$ & - & - & $\sqrt{ }$ & $\sqrt{ }$ & - & - & - & $\sqrt{ }$ & 3 & $37.5 \%$ \\
\hline 6 & $\begin{array}{l}\text { English teacher } \\
\text { uses backward } \\
\text { building up } \\
\text { technique. }\end{array}$ & $\sqrt{ }$ & $\sqrt{ }$ & - & $\sqrt{ }$ & $\sqrt{ }$ & $\sqrt{ }$ & $\sqrt{ }$ & - & 6 & $75 \%$ \\
\hline 7 & $\begin{array}{c}\text { English teacher } \\
\text { uses bingo } \\
\text { technique }\end{array}$ & - & $\sqrt{ }$ & - & $\sqrt{ }$ & - & - & $\sqrt{ }$ & - & 3 & $37.5 \%$ \\
\hline 8 & $\begin{array}{c}\text { English teacher } \\
\text { uses } \\
\text { brainstorming } \\
\text { technique. }\end{array}$ & - & $\sqrt{ }$ & $\sqrt{ }$ & - & $\sqrt{ }$ & $\sqrt{ }$ & - & - & 4 & $50 \%$ \\
\hline 9 & $\begin{array}{c}\text { English teacher } \\
\text { uses }\end{array}$ & $\sqrt{ }$ & - & - & - & - & - & $\sqrt{ }$ & - & 2 & $25 \%$ \\
\hline
\end{tabular}




\begin{tabular}{|c|c|c|c|c|c|c|c|c|c|c|c|}
\hline & $\begin{array}{l}\text { categorizing } \\
\text { technique }\end{array}$ & & & & & & & & & & \\
\hline 10 & $\begin{array}{c}\text { English teacher } \\
\text { uses chain } \\
\text { stories } \\
\text { technique. }\end{array}$ & - & - & $\sqrt{ }$ & - & $\sqrt{ }$ & $\sqrt{ }$ & - & - & 3 & $37.5 \%$ \\
\hline 11 & $\begin{array}{l}\text { English teacher } \\
\text { uses dialoques } \\
\text { technique }\end{array}$ & - & $\sqrt{ }$ & $\sqrt{ }$ & - & $\sqrt{ }$ & - & - & $\sqrt{ }$ & 4 & $50 \%$ \\
\hline 12 & $\begin{array}{c}\text { English teacher } \\
\text { uses } \\
\text { exaggeration } \\
\text { technique }\end{array}$ & - & - & $\sqrt{ }$ & - & $\sqrt{ }$ & - & - & - & 2 & $25 \%$ \\
\hline & TOTAL & 5 & 7 & 5 & 6 & 9 & 5 & 4 & 5 & & \\
\hline \multicolumn{2}{|r|}{ Percentage (\%) } & $41.6 \%$ & $\begin{array}{c}58.3 \\
\%\end{array}$ & $41.6 \%$ & $50 \%$ & $75 \%$ & $41.6 \%$ & $33.3 \%$ & $41.6 \%$ & & $47.9 \%$ \\
\hline
\end{tabular}

\subsection{The Interview Result of English Teacher dealing with the techniques in improving students pronouncing word loudly.}

Besides presenting data gathered from observation, the researcher also collects the data from interview intended to figure out the teaching knowledge about the teacher's techniques in improving students pronouncing words aloud. So, the questions given by the researcher to the teachers were regarding the technique applied. This interview was qualitative aiming to supporting the data of observation. The data from this interview were directly asked to the English teacher, and here are the data gotten from interview, as follows:

1. In your opinion, how many techniques do you apply in improving students pronouncing words loudly?

There are many techniques I apply to improve students pronouncing words loudly, they are: drill, repetition, exercise, backward building up. All the technique help the students to practice and improve their pronunciation. Because they are involved in the process of learning pronunciation.

2. From the various techniques you stated which technique do you frequently apply in improving students pronouncing words loudly?

"In teaching prononciation I always use repetition technique because that technique is suitable for my students especially in the first grade. If we always repeat the word in teaching pronunciation I think the student easly understand. I motivate them by giving score. If they want to get a high score, they must pronounce the word loudly in front of the class. So, some of them can study hard to pronounce the words. But when some of them are still shy to pronounce the word, and do not want to pronounce the word in front of the class, I give them chance to practice their pronunciation in next meetings. So, they can study at home first, after that they can continue their practice in pronunciation.

3. Why do you apply the repetition technique?

I apply this techniques because it can be easy to improve students pronouncing words loudly. Since the students are shy to pronounce, apraid of making mistake. In language 
teaching for practicing sound or sentence pattern in language based on the guided repetition or practice.

4. Is the technique you apply fit with students proficiency in improving students pronouncing words loudly?

Yes. It is during I apply this technique it seem to be affective and fit with the students language proficiency especially for improving students pronouncing words loudly.

\section{Discussion}

To analyze the teachers' techniques in improving students pronouncing word loudly, the researcher completes the information through interview. There are some techniques implemented well by both of teacher in improving students pronouncing word loudly at the first year of MAN Batam. The techniques namely:

\subsection{Drilling or Repetition techniques}

Learners practice a sentence or phrase by repeating the last word, then adding another word with each repitation until the whole sentence or phrase has been produce. Based on the data that have been collected from observation and interview, it can be seen that the teacher use driling or repetition technique to improve students pronouncing word loudly activities in class room. So, not all of the students practice their pronunciation and present their result in pronouncing word loudly. This technique is frequently use by the teacher.

\subsection{Backward building up}

Based on the findings, it is clear that English Teacher do backward building up technique to improve students pronouncing words loudly at the first year of MAN Batam, this technique is important in teaching pronunciation. While, there are some techniques are not implemented well, as seen as follows Bingo, Categorizing, Chain stories, Dialogues, Exaggeration, Identification, Information gap, and Mirrors.

Based on the formulation of the research, the analysis data resulting that both of teacher are still less to apply the techniques to improve students pronouncing words loudly and this fact can be seen from the techniques are not implemented by the teacher. Moreover, the researcher sees that one of techniques to improve students pronouncing because it makes the students tend to be relax and feel enjoyable study English. This can stimulate the students in order that the students are not nervous when starting pronouncing words loudly.

Then, the researcher sees that both of teacher are only implemented the techniques such as Drilling or Repetition techniques and backward building up because that technique are useful in improving students pronouncing words loudly. How to implement drilling technique or repetition is the Learners practice a sentence or phrase by repeating the last word, then adding another word with each repetition until the whole sentence or phrase has been produce.

Based on the data that have been collected from observation and interview, it can be seen that the teacher use drilling or repetition technique to improve students pronouncing word loudly activities in class room. So, not all of the students practice their pronunciation and present their result in pronouncing word loudly. And it is clear that English Teacher implement backward building up technique to improve students pronouncing words loudly at the first year of MAN Batam, this technique is important in teaching pronunciation. 
Meanwhile, the techniques are not implemented by the teacher are the teacher motivates the students to pronounce words loudly by practicing the word, and asks the students to deep breathing before starting pronunciation. Thus, the teacher is categorized into good.

Based on the observation and interview used by the researcher, the researcher tries to analyze the teacher frequently technique used in improving students pronouncing words loudly at the first year of MAN Batam. The researcher knows that the teacher taught very well. It can be seen from how he explained the material and managed the class discussion. Teaching material is very important for a teacher in teaching learning process. The material should be appropriated to the syllabus and the student's needs. It must be able to increase the student's competence and knowledge (Suadi, 2020; Yoniswan, 2020)

In teaching pronunciation, the teacher should follow the curriculum applied in that school. Educational program is needed to design the curriculum. Curriculum is the principles and procedures for planning, implementing, evaluating, and managing of an educational program. By applying the curriculum, the duty of the teacher is easier because it contains the goal, syllabus, and teaching material.

The researcher finds that the teacher uses media effectively. Media as such things that can be used to distribute the message from sender or receiver to stimulate the sense, mind, attention, and the students' interest to build the teaching learning process. The English teacher of MAN Batam uses a media namely whiteboard. Traditionally, he wrote the material on the board by using board marker, the material namely some words and ask the students to repeat the words and students give full attention for the teacher's explanation.

From the explanation above it is clear that the teacher frequently used the technique of repetition or drilling. And to identify what might made the teacher prefer the technique, the research sees from the explanation of the teacher. And the teachers prefer drilling technique. There are many advantages for drilling technique, namely (1) the students more active and pay good attention, because they are involved in the process of learning, (2) the students always practice in saying the words, and (3) improving student's motivation and skill in pronouncing English words. From the explanation above, it is clear that the teacher prefer drilling technique in improving students pronouncing words loudly.

\section{Conclusion}

The study has documented several techniques used by teachers to improve students' pronunciation. The techniques used by the teachers in improving student pronouncing words loudly are English teacher uses driling techniques how to pronounce the word. English teacher uses repetition techniques to practice and improve students pronouncing and backward building up techniques to improve students pronouncing. Moreover, English teacher supervises the students' activity to pronounce the word. The repetition drill technique is the most frequently used by the teacher. The teacher prefer the repetition technique because it is easy to improve students' pronouncion. And there are many factors that the teacher prefer the technique are native language, age, exposure, innate phonetic ability, identity and language ego, motivation and concern for good pronunciation, and internal and external factors. 


\section{References}

Arikunto, Suharsimi. (1996). Prosedur Penelitian Suatu Pendekatan Praktis. Jakarta: PT Rineka Cipta.

Crutten, Alan. (2008). Gimson's Pronunciation of English. London: Replika Press

Danim, Sudarwan. (1995). Media Komunikasi Pendidikan. Jakarta: Bumi Aksara

Douglas, Brown, H. (1994). Teaching by Principle: An Interactive Approach to Language Pedagogy. Englewood Cliffs, Mew Jersey: Prentice Hall Regents.

Harmer, Jeremy. (2001). The Practice of English Language Teaching. Malaysia: Longman.

Hasibuan, Kalayo. (2007). Teaching English as a Foreign Language (TEFL). Pekanbaru: UIN SUSKA Press.

Kelly, Gerrald. (2000). How to Teach Pronunciation. England. Bluestone Press

Korkut, P., \& Çelik, Ö. (2018). Developing pronunciation through creative drama. The Language Learning Journal, 1-13.

Kunandar. (2007). Guru Profesional Implementasi KTSP dan Penerapan Menghadapi Sertifikasi Guru. Jakrta: PT Raja Grafindo Persada.

Lavery, Clare. (2001). Language Assistant. The British Council.

Maslizawati. (2004). 'Teaching Speaking through Yes-No Question Game to the Third Year of Junior High School', Tehsis UIN.

Nazir, Moh. (2003). Metode Penelitian. Jakarta: Ghalia Indonesia.

Nurhasanah. (2002). "'A Descriptive Study on the Efforts to Improve Pronunciation Accuracy of the fourth Year Students of Department of English Education of Tarbiyah Faculty Sultan Syarif Kasim Riau. Pekanbaru': Unpublished.

Ovando, J. Carlos. (2003). Bilingual and ESL Classroom. New York.

Pedrazzini, L. (2016). The Principle of "Correct Pronunciation": Teaching English as a Foreign Language in the Early Twentieth Century. Language \& History, 59(1), 63-72.

Richards, Jack C. (1999). Longman Dictionary of Language Teaching and Applied Linguitics. London: Longman.

Salamah, Umi. (2007). 'A Study on Teachers' Effort in Developing the Students' English Proficiency at Junior High Schools in Seberida'. Pekanbaru: Unpublished Thesis

Suadi. (2020). Improving students' English speaking skill by using their speaking video recording. SALEE: Study of Applied Linguistics and English Education, 1(01), 1-10.

Sudijono, Anas. (2004). Pengantar Statistik Pendidikan. Jakarta: PT Raja Grafindo.

Usman, Moh. Uzher. (2006). Menjadi Guru Profesional. Bandung: PT Remaja Rosdakarya.

Yoniswan. (2020). Effects of role-play on Indonesian junior high school students' speaking skills: A classroom action research study. SALEE: Study of Applied Linguistics and English Education, 1(02), 1-9. 